\title{
QUEEN'S
UNIVERSITY
BELFAST
}

\section{Understanding the interaction between active sites and sorbents during the integrated carbon capture and utilization process}

Sun, H., Wang, Y., Xu, S., Osman, A. I., Stenning, G., Han, J., Sun, S., Rooney, D., Williams, P. T., Wang, F., \& $\mathrm{Wu}, \mathrm{C}$. (2021). Understanding the interaction between active sites and sorbents during the integrated carbon capture and utilization process. Fuel, 286(Part 1), [119308]. https://doi.org/10.1016/j.fuel.2020.119308

\section{Published in:}

Fuel

\section{Document Version:}

Peer reviewed version

Queen's University Belfast - Research Portal:

Link to publication record in Queen's University Belfast Research Portal

\section{Publisher rights}

Copyright 2020 Elsevier.

This manuscript is distributed under a Creative Commons Attribution-NonCommercial-NoDerivs License

(https://creativecommons.org/licenses/by-nc-nd/4.0/), which permits distribution and reproduction for non-commercial purposes, provided the author and source are cited.

\section{General rights}

Copyright for the publications made accessible via the Queen's University Belfast Research Portal is retained by the author(s) and / or other copyright owners and it is a condition of accessing these publications that users recognise and abide by the legal requirements associated with these rights.

Take down policy

The Research Portal is Queen's institutional repository that provides access to Queen's research output. Every effort has been made to ensure that content in the Research Portal does not infringe any person's rights, or applicable UK laws. If you discover content in the Research Portal that you believe breaches copyright or violates any law, please contact openaccess@qub.ac.uk. 


\section{Understanding the interaction between active sites and sorbents during the integrated carbon capture and utilization Process}

Hongman Sun ${ }^{\mathrm{a}}$, Yehong Wang ${ }^{\mathrm{b}}$, Shaojun $\mathrm{Xu}^{\mathrm{c}, \mathrm{d}}$, Ahmed I. Osman ${ }^{\mathrm{a}}$, Gavin Stenning, Jianyu Han ${ }^{\mathrm{b}}$, Shuzhuang Sun ${ }^{\mathrm{a}}$, David Rooney ${ }^{\mathrm{a}}$, Paul T. Williams ${ }^{\mathrm{f}, *}$, Feng Wang ${ }^{\mathrm{b}, *}$ and Chunfei $\mathrm{Wu}^{\mathrm{a}, *}$

${ }^{a}$ School of Chemistry and Chemical Engineering, Queen's University Belfast, Belfast, BT7 1NN, UK

${ }^{b}$ State Key Laboratory of Catalysis, Dalian National Laboratory for Clean Energy, Dalian Institute of Chemical Physics, Chinese Academy of Sciences, Dalian, 116023, China

${ }^{c}$ UK Catalysis Hub, Research Complex at Harwell, Didcot, OX11 OFA, UK

${ }^{d}$ Cardiff Catalysis Institute, School of Chemistry, Cardiff University, Cardiff, CF10 3AT, UK ${ }^{e}$ ISIS Neutron and Muon Source, Rutherford Appleton Laboratory, Didcot, OX11 0QX, UK

${ }^{f}$ School of Chemical and Process Engineering, University of Leeds, Leeds, LS2 9JT, UK.

*Corresponding authors: E-mail: c.wu@qub.ac.uk(C.Wu); wangfeng@dicp.ac.cn (F.Wang); p.t.williams@leeds.ac.uk(P.T.Williams). 


\begin{abstract}
The distance between catalytic sites $(\mathrm{Ni})$ and sorbents $(\mathrm{CaO})$ on the performance of integrated $\mathrm{CO}_{2}$ capture and utilization (ICCU) process is crucial important because the sorbents demonstrate a dramatic volume increase during carbonation reaction $\left(1^{\text {st }}\right.$ stage of ICCU) and sequentially cover the catalytic sites and retard the $\mathrm{CO}_{2}$ conversion ( $2^{\text {nd }}$ stage of ICCU). Herein, we synthesized various $\mathrm{Ni} / \mathrm{CaO}$-based dual functional materials (DFMs) with different distances between active sites and sorbents to provide different volume spaces for the growth of $\mathrm{CaCO}_{3}$ during the carbonation reaction. It is found that both $1 \% \mathrm{NiCaO}$ and $10 \% \mathrm{NiCaO}$ synthesized by a one-pot method exhibited a low $\mathrm{CO}_{2}$ conversion (38\% and 45\%, respectively) and $\mathrm{CH}_{4}$ selectivity (58\% and $69 \%$, respectively) as the distance between catalytic sites and sorbents was so close that the Ni active sites were covered by the formed $\mathrm{CaCO}_{3}$ during carbonation reaction. With the increase of the distance by physical mixing method, the $\mathrm{CO}_{2}$ conversion and $\mathrm{CH}_{4}$ selectivity of $1 \% \mathrm{Ni} / \mathrm{CeO}_{2}-\mathrm{CaO}$-phy were largely increased to $62 \%$ and $84 \%$, respectively at $550{ }^{\circ} \mathrm{C}$ and atmospheric pressure when captured $\mathrm{CO}_{2}$ from $15 \% \mathrm{CO}_{2} / \mathrm{N}_{2}$. This is attributed to the fact that the $\mathrm{Ni}$ active sites were still well dispersed on the surface of $\mathrm{CeO}_{2}$ nanorods instead of being covered by the newly formed $\mathrm{CaCO}_{3}$.
\end{abstract}

KEYWORDS: Integrated carbon capture and utilization process, dual functional materials, volume increase, active sites, methane. 


\section{Introduction}

Reducing the concentration of atmospheric carbon dioxide $\left(\mathrm{CO}_{2}\right)$ has drawn significant attention due to the issues of global warming and serious climate change $[1,2] \cdot \mathrm{CO}_{2}$ capture using CaO-based sorbents (calcium looping, $\mathrm{CaL}$ ) is regarded as one of the most effective strategies to meet the target of reducing $\mathrm{CO}_{2}$ emissions $[3,4]$. This is because $\mathrm{CaO}$-based sorbents demonstrate a high theoretical capture capacity of $17.8 \mathrm{mmol} \mathrm{g}^{-1}$ and a low cost of $\$ 16-44$ per ton $\mathrm{CO}_{2}$ capture, which is more competitive than that of amine scrubbing at $\$ 32-80$ per ton $\mathrm{CO}_{2}$ capture $[5,6]$. The current state-ofthe-art of $\mathrm{CaL}$ includes $\mathrm{CO}_{2}$ capture and sorbent regeneration in a separated reactor system with high temperature. This is not only energy-intensive but also very challenging, for example, attrition of sorbent during the transportation between carbonator and calciner [7]. Therefore, a novel integrated carbon capture and utilization (ICCU) process has been proposed, which has two stages performed in a single reactor at the same temperature as shown in Fig. S1 [8-10]. The $1^{\text {st }}$ stage captures $\mathrm{CO}_{2}$ from flue gas using sorbents and the $2^{\text {nd }}$ stage converts the captured $\mathrm{CO}_{2}$ into value-added products such as carbon monoxide $(\mathrm{CO})$ and methane $\left(\mathrm{CH}_{4}\right)$ etc., by switching the feed gas to renewable $\mathrm{H}_{2}$. This novel ICCU process will reduce the energy required for the sorbent regeneration and the infrastructure utilized in $\mathrm{CO}_{2}$ transportation and storage [11-14].

Recently, the ICCU process combining carbon capture using CaO-based materials with the reverse water gas shift reaction (RWGS, Eq. (1)) or dry reforming of methane/ethane (Eq. (2)/Eq. (3)) has been proposed because the $\mathrm{CaO}$-based materials are high-temperature sorbents for $\mathrm{CO}_{2}$ capture [1517]. Our previous work has successfully converted the captured $\mathrm{CO}_{2}$ into $\mathrm{CO}$ at $650{ }^{\circ} \mathrm{C}$ by the $\mathrm{ICCU}$ process using Ni-doped $\mathrm{CaO}$-based dual functional materials (DFMs) which were synthesized by a one-pot sol-gel method. The DFMs exhibited good stability for CO production after 20 cycles of the ICCU process [15]. Kim et al. proposed an ICCU process converting two major greenhouse gases 
$\left(\mathrm{CO}_{2}\right.$ and $\left.\mathrm{CH}_{4}\right)$ via dry reforming into a mixture of $\mathrm{CO}$ and $\mathrm{H}_{2}$ by a physical mixture of $\mathrm{CaO}$ sorbent and $\mathrm{Ni} / \mathrm{MgO} / \mathrm{Al}_{2} \mathrm{O}_{3}$ catalyst [16]. The synthesized DFMs demonstrated almost full conversion of the captured $\mathrm{CO}_{2}$ at $720{ }^{\circ} \mathrm{C}$.

$$
\begin{aligned}
& \mathrm{CO}_{2}+\mathrm{H}_{2} \leftrightarrow \mathrm{CO}+\mathrm{H}_{2} \mathrm{O}, \Delta \mathrm{H}_{\mathrm{r}, 298 \mathrm{~K}}=+41.2 \mathrm{~kJ} \mathrm{~mol}^{-1} \\
& \mathrm{CO}_{2}+\mathrm{CH}_{4} \leftrightarrow 2 \mathrm{CO}+2 \mathrm{H}_{2}, \Delta \mathrm{H}_{\mathrm{r}, 298 \mathrm{~K}}=+247 \mathrm{~kJ} \mathrm{~mol}^{-1} \\
& 2 \mathrm{CO}_{2}+\mathrm{C}_{2} \mathrm{H}_{6} \leftrightarrow 4 \mathrm{CO}+3 \mathrm{H}_{2}, \Delta \mathrm{H}_{\mathrm{r}, 298 \mathrm{~K}}=+429 \mathrm{~kJ} \mathrm{~mol}^{-1} \\
& \mathrm{CO}_{2}+4 \mathrm{H}_{2} \leftrightarrow \mathrm{CH}_{4}+2 \mathrm{H}_{2} \mathrm{O}, \Delta \mathrm{H}_{\mathrm{r}, 298 \mathrm{~K}}=-164 \mathrm{~kJ} \mathrm{~mol}^{-1}
\end{aligned}
$$

In addition, the ICCU process combining carbon capture with the Sabatier reaction (Eq. (4)) has attracted great interests due to the existence of the established infrastructure for $\mathrm{CH}_{4}$ applications [1820]. For example, Duyar et al. developed $\mathrm{Ru} / \mathrm{CaO}$ DFMs for the ICCU process and reported a relatively low $\mathrm{CH}_{4}$ yield of $0.5 \mathrm{mmol} \mathrm{g}^{-1}$, which was mainly attributed to the low loading of sorbent [17]. However, the desired temperature of Ru-based catalysts for $\mathrm{CO}_{2}$ methanation is from 200-300 ${ }^{\circ} \mathrm{C}$, which is much lower than that of carbon capture using $\mathrm{CaO}$-based sorbents [21]. In addition, high cost and low poisoning resistance limit the industrial application of Ru-based catalysts. Ni-based catalysts could be promising candidates in the proposed ICCU process not only because they are costeffective, but also because they provide a match in terms of catalytic temperature for $\mathrm{CO}_{2}$ methanation and $\mathrm{CO}_{2}$ capture using $\mathrm{CaO}-$ based DFMs [22, 23].

However, using the cost-effective $\mathrm{Ni} / \mathrm{CaO}$ DFMs has not been reported for the novel ICCU process to produce $\mathrm{CH}_{4}$. Furthermore, a dramatic increase of volume from $\mathrm{CaO}\left(16.9 \mathrm{~cm}^{3} \mathrm{~mol}^{-1}\right)$ to $\mathrm{CaCO}_{3}$ $\left(34.1 \mathrm{~cm}^{3} \mathrm{~mol}^{-1}\right)$ happens after the carbonation reaction [24]. This could cause the coverage of $\mathrm{Ni}$ active sties by $\mathrm{CaCO}_{3}$ and result in the insufficient conversion of the captured $\mathrm{CO}_{2}$. Therefore, understanding the interaction between $\mathrm{Ni}$ active sites and $\mathrm{CaO}$-based sorbents, especially the distance is essential for the design of efficient DFMs for $\mathrm{CH}_{4}$ production during the ICCU process. In this 
report, we synthesized various $\mathrm{Ni} / \mathrm{CaO}$-based $\mathrm{DFMs}$ with different distances between active sites and sorbents and investigated the influence of sorbent volume change during the carbonation stage on the utilization of captured $\mathrm{CO}_{2}$. In the DFMs, $\mathrm{Ni}$ species are the active sites for $\mathrm{CO}_{2}$ conversion, $\mathrm{CaO}$ is the sorbent used for $\mathrm{CO}_{2}$ capture, and $\mathrm{CeO}_{2}$ is used as a physical barrier to increase the distance between active sites and sorbents.

\section{Experimental section}

\subsection{Materials synthesis}

\subsubsection{DFMs synthesized by one-pot method}

The one-pot method to synthesize DFMs, predetermined amounts of $\mathrm{Ca}\left(\mathrm{NO}_{3}\right)_{2} \cdot 4 \mathrm{H}_{2} \mathrm{O}$ (SigmaAldrich), $\mathrm{Ni}\left(\mathrm{NO}_{3}\right)_{2} \cdot 6 \mathrm{H}_{2} \mathrm{O}$ (Sigma-Aldrich) and citric acid monohydrate (Sigma-Aldrich) acting as the chelation agent were added to deionized water at room temperature. The mixture was continuously stirred at $80{ }^{\circ} \mathrm{C}$, dried at $120{ }^{\circ} \mathrm{C}$ overnight, and calcined at $850{ }^{\circ} \mathrm{C}$ for $2 \mathrm{~h}$ with a heating rate of $2{ }^{\circ} \mathrm{C}$ $\min ^{-1}$. The molar ratios of water and citric acid to $\mathrm{Ca}^{2+}$ were $40: 1$ and $1: 1$, respectively. The molar ratios of $\mathrm{Ni}^{2+}$ to $\mathrm{Ca}^{2+}$ were $0.01: 1$ and $0.1: 1$ for $1 \% \mathrm{NiCaO}$ and $10 \% \mathrm{NiCaO}$, respectively.

\subsubsection{DFMs synthesized by wet impregnation method}

The wet impregnation method was used to synthesize DFMs and two types of supports in the form of $\mathrm{CeCaO}$ and $\mathrm{CeCaCO}_{3}$ were used. For the synthesis of $\mathrm{CeCaO}$, predetermined amounts of $\mathrm{Ce}\left(\mathrm{NO}_{3}\right)_{3} \cdot 6 \mathrm{H}_{2} \mathrm{O}$ (Sigma-Aldrich), $\mathrm{Ca}\left(\mathrm{NO}_{3}\right)_{2} \cdot 4 \mathrm{H}_{2} \mathrm{O}$ and citric acid monohydrate were added to deionized water at room temperature (The molar ratio of water, citric acid and $\mathrm{Ce}^{3+}$ to $\mathrm{Ca}^{2+}$ were $40: 1$, 1:1 and $0.033: 1$, respectively). The mixture was continuously stirred at $80{ }^{\circ} \mathrm{C}$, dried at $120{ }^{\circ} \mathrm{C}$ overnight. The obtained products were calcined at $850{ }^{\circ} \mathrm{C}$ for $2 \mathrm{~h}$ with a heating rate of $2{ }^{\circ} \mathrm{C} \min ^{-1}$. 
$\mathrm{CeCaCO}_{3}$ was prepared by the carbonation of $\mathrm{CeCaO}$ in $15 \% \mathrm{CO}_{2} / \mathrm{N}_{2}\left(50 \mathrm{~mL} \mathrm{~min}^{-1}\right)$ at $550{ }^{\circ} \mathrm{C}$ for 60 $\min$.

After the production of the two types of supports, a predetermined amount of $\mathrm{Ni}\left(\mathrm{NO}_{3}\right)_{2} \cdot 6 \mathrm{H}_{2} \mathrm{O}$ was dissolved into $16 \mathrm{~mL}$ deionized water and then $0.8 \mathrm{~g}$ as-prepared supports were added. The mixture was stirred at room temperature for $8 \mathrm{~h}$ before the evaporation of water at $80{ }^{\circ} \mathrm{C}$ and then dried overnight. The obtained DFMs are designated as $1 \% \mathrm{Ni} / \mathrm{CeCaO}$-imp and $1 \% \mathrm{Ni} / \mathrm{CeCaCO}_{3}$-imp when using $\mathrm{CeCaO}$ and $\mathrm{CeCaCO}_{3}$, respectively.

\subsubsection{Synthesis of $\mathrm{CeO}_{2}$ nanorods}

$\mathrm{CeO}_{2}$ nanorods were synthesized by a hydrothermal process as previously reported [21, 25]. Solution A (1.730 $\mathrm{g} \mathrm{Ce}\left(\mathrm{NO}_{3}\right)_{3} \cdot 6 \mathrm{H}_{2} \mathrm{O}$ dissolved in $10 \mathrm{~mL}$ of deionized water) was added to solution $\mathrm{B}(20.0 \mathrm{~g}$ $\mathrm{NaOH}$ (Sigma-Aldrich) dissolved in $70 \mathrm{~mL}$ of deionized water) and the mixture was stirred for 30 min. Subsequently, the mixture was transferred into a stainless-steel auto-clave and kept at $100{ }^{\circ} \mathrm{C}$ for $24 \mathrm{~h}$. After cooling down to room temperature, the products were filtered and washed by deionized water and ethanol until the $\mathrm{pH}$ reached 7. Finally, the products were dried at $80{ }^{\circ} \mathrm{C}$ overnight to obtain $\mathrm{CeO}_{2}$ nanorods.

\subsubsection{DFMs synthesized by physical mixing method}

The physical mixing method for the synthesis of DFMs has three steps. The first step is the synthesis of $\mathrm{CaO}$ sorbent using a one-pot method (the detailed method is demonstrated in section 2.1.1 without the addition of $\mathrm{Ni}$ precursor). The second step is dispersing $\mathrm{Ni}$ active sites on the synthesized $\mathrm{CeO}_{2}$ nanorods (detailed method for the synthesis of $\mathrm{CeO}_{2}$ nanorods is described in section 2.1.3). The third step is mixing the sorbent and catalyst physically with a mass ratio of $1: 1$. The DFM synthesized by the physical mixing method is designated as $1 \% \mathrm{Ni} / \mathrm{CeO}_{2}-\mathrm{CaO}-$ phy.

The detailed sample information is summarized in Table 1. 
Table 1 Summary of sample information

\begin{tabular}{|c|c|c|c|}
\hline Sample name & Method & $\begin{array}{l}\mathrm{NiO} \\
\text { loading }\end{array}$ & Function \\
\hline $\mathrm{CeO}_{2}$ & Hydrothermal & I & Support and reference \\
\hline $\mathrm{CaO}-\mathrm{CeO}_{2}$ & Physical mixing & / & Support and reference \\
\hline $1 \% \mathrm{NiCaO}$ & One-pot & $1 \%$ & DFMs with $1 \mathrm{wt} . \% \mathrm{Ni}$ \\
\hline $10 \% \mathrm{NiCaO}$ & One-pot & $10 \%$ & DFMs with 10wt.\% Ni \\
\hline $1 \% \mathrm{Ni} / \mathrm{CeCaO}-\mathrm{imp}$ & $\begin{array}{l}\text { Wet impregnation for catalyst } \\
(\mathrm{Ni} / \mathrm{CeCaO}) \text { and one-pot for } \\
\text { support }(\mathrm{CeCaO})\end{array}$ & $1 \%$ & $\begin{array}{l}\text { DFMs promoted by Ce with } \\
1 \mathrm{wt} \% \mathrm{Ni}\end{array}$ \\
\hline $1 \% \mathrm{Ni} / \mathrm{CeCaCO}_{3}$-imp & $\begin{array}{l}\text { Wet impregnation for catalyst } \\
\left(\mathrm{Ni} / \mathrm{CeCaCO}_{3}\right) \text { and one-pot for } \\
\text { support }\left(\mathrm{CeCaCO}_{3}\right)\end{array}$ & $1 \%$ & $\begin{array}{l}\text { Carbonized DFMs promoted } \\
\text { by Ce with } 1 \mathrm{wt} . \% \mathrm{Ni}\end{array}$ \\
\hline $1 \% \mathrm{Ni} / \mathrm{CeO}_{2}-\mathrm{CaO}-$ phy & $\begin{array}{l}\text { Wet impregnation for catalyst } \\
\left(1 \% \mathrm{Ni} / \mathrm{CeO}_{2}\right) \text { and physical } \\
\text { mixing with sorbent }\end{array}$ & $1 \%$ & $\begin{array}{l}\text { DFMs with } 1 \text { wt. } \% \mathrm{Ni} \text { and } \\
\text { physical mixed catalytic sites } \\
\text { and sorbents }\end{array}$ \\
\hline
\end{tabular}

\subsection{Material characterization}

Powder X-ray diffraction (XRD) patterns ranging from 10 to $80^{\circ}$ were collected by a PANalytical empyrean series 2 diffractometer with $\mathrm{Cu} \mathrm{Ka} \mathrm{X-ray} \mathrm{source.} \mathrm{X'pert} \mathrm{Highscore} \mathrm{plus} \mathrm{software} \mathrm{was}$ utilized to analyse the data. The in-situ powder X-ray diffraction patterns were measured on a Rigaku smartlab X-ray diffractometer equipped with an in-situ gas cell (Anton-paar HTK-1200N high

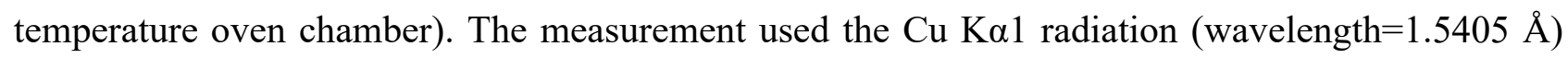
from $3^{\circ}$ to $90^{\circ}$ with a scan speed of $5.5^{\circ} \mathrm{min}^{-1}$. The sample was firstly reduced in $10 \% \mathrm{H}_{2} / \mathrm{N}_{2}$ at 60 $\mathrm{mL} \min ^{-1}$ for $8 \mathrm{~h}$, and then transferred into the in-situ gas cell. The sample was then heated to $500{ }^{\circ} \mathrm{C}$ at a $5{ }^{\circ} \mathrm{C} \mathrm{min}^{-1}$ rate under $\mathrm{N}_{2}\left(100 \mathrm{~mL} \mathrm{~min}^{-1}\right)$ in the cell, following pure $\mathrm{CO}_{2}$ at a $60 \mathrm{~mL} \mathrm{~min}^{-1}$ for $1 \mathrm{~h}$. Transmission electron microscopy (TEM, JEOL 2010) was utilized to characterize the structure of DFMs. The samples were ultrasonically dispersed in absolute acetone and dropped cast on carbon- 
coated $\mathrm{Cu}$ grids. High angle annular dark field (HAADF) images were carried out using a scanning transmission electron microspore (STEM, FEI Titan3 Themis 300) operating at $300 \mathrm{kV}$ with FEI Super-X 4-detector EDX system. The cross-section images were performed using high-resolution scanning electron microscopy (SEM) coupled with a focused ion beam (FIB). The element distribution was collected by energy-dispersive X-ray spectroscopy (EDX). CO chemisorption performed on Micromeritics Autochem II 2920 analyser was utilized for the calculation of $\mathrm{Ni}$ dispersion for fresh reduced DFMs and reduced DFMs after the carbonation reaction. The samples, around $100 \mathrm{mg}$, were placed into a U-shape quartz tube and reduced at $350{ }^{\circ} \mathrm{C}$ in $5 \% \mathrm{H}_{2} / \mathrm{N}_{2}$ for 30 min. After reduction, the temperature was further increased to $450{ }^{\circ} \mathrm{C}$ to remove the absorbed $\mathrm{H}_{2}$ using pure helium for $90 \mathrm{~min} .1 \% \mathrm{CO} / \mathrm{He}$ and $\mathrm{He}$ were used for the loop gas and carrier gas, respectively during the pulse chemisorption at $35{ }^{\circ} \mathrm{C}$. The regulation for setting the reduction temperature for CO chemisorption is displayed in Fig. S2. A thermogravimetric analyzer (TGA, SDT Q600) was utilized to measure the weight percentage change during the ICCU process.

\subsection{Integrated $\mathrm{CO}_{2}$ capture and utilization}

The ICCU performance of various DFMs was performed in a vertical fixed-bed reactor under atmospheric pressure. Typically, a predetermined amount $(\sim 0.3 \mathrm{~g})$ of powdered DFMs mixed with $1.0 \mathrm{~g}$ of quartz sand was loaded into the reactor and quartz wool was used to fix the sample. A k-type thermocouple was utilized to detect the temperature of the sample. The detailed sample information used in the ICCU process is summarized in Table 1. The $1^{\text {st }}$ stage (carbonation reaction) was conducted in $15 \% \mathrm{CO}_{2} / \mathrm{N}_{2}\left(50 \mathrm{~mL} \mathrm{~min}{ }^{-1}\right)$ at $550{ }^{\circ} \mathrm{C}$ for $60 \mathrm{~min}$. Subsequently, the feed gas was switched to pure $\mathrm{H}_{2}\left(50 \mathrm{~mL} \mathrm{~min}^{-1}\right)$ to convert the captured $\mathrm{CO}_{2}$ into $\mathrm{CH}_{4}$ at the same temperature after the reactor was purged for 5 min using pure $\mathrm{N}_{2}$. The products of the carbon capture stage and the conversion stage were collected in gas sample bags separately and analysed by off-line gas chromatography (GC, Techcomp 7900, TCD detector, TDX-01 column) with $\mathrm{N}_{2}$ as the internal 
standard. The $\mathrm{CO}_{2}$ capture capacity per gram of sorbent is defined as the difference between the recorded $\mathrm{CO}_{2}$ concentrations in the outlet gas stream and a blank experiment without any $\mathrm{CO}_{2}$ sorbent. The product yield including $\mathrm{CH}_{4}$ yield, $\mathrm{CO}$ yield and $\mathrm{CO}_{2}$ yield is defined as per gram of catalyst. The calculation of carbon balance, $\mathrm{CO}_{2}$ conversion, and $\mathrm{CH}_{4}$ selectivity are described as follows:

$$
\begin{aligned}
& \text { Carbon balance }=\frac{\mathrm{CH}_{4} \text { yield }+\mathrm{CO}_{2} \text { yield }+\mathrm{CO} \text { yield }}{\mathrm{CO}_{2} \text { capture capacity }} * 100 \% \\
& \mathrm{CO}_{2} \text { conversion }=\frac{\mathrm{CH}_{4} \text { yield }+\mathrm{CO} \text { yield }}{\mathrm{CO}_{2} \text { capture capacity }} * 100 \% \\
& \mathrm{CH}_{4} \text { selectivity }=\frac{\mathrm{CH}_{4} \text { yield }}{\mathrm{CH}_{4} \text { yield }+\mathrm{CO} \text { yield }} * 100 \%
\end{aligned}
$$

\section{Results and discussion}

\subsection{Characterization of fresh materials}
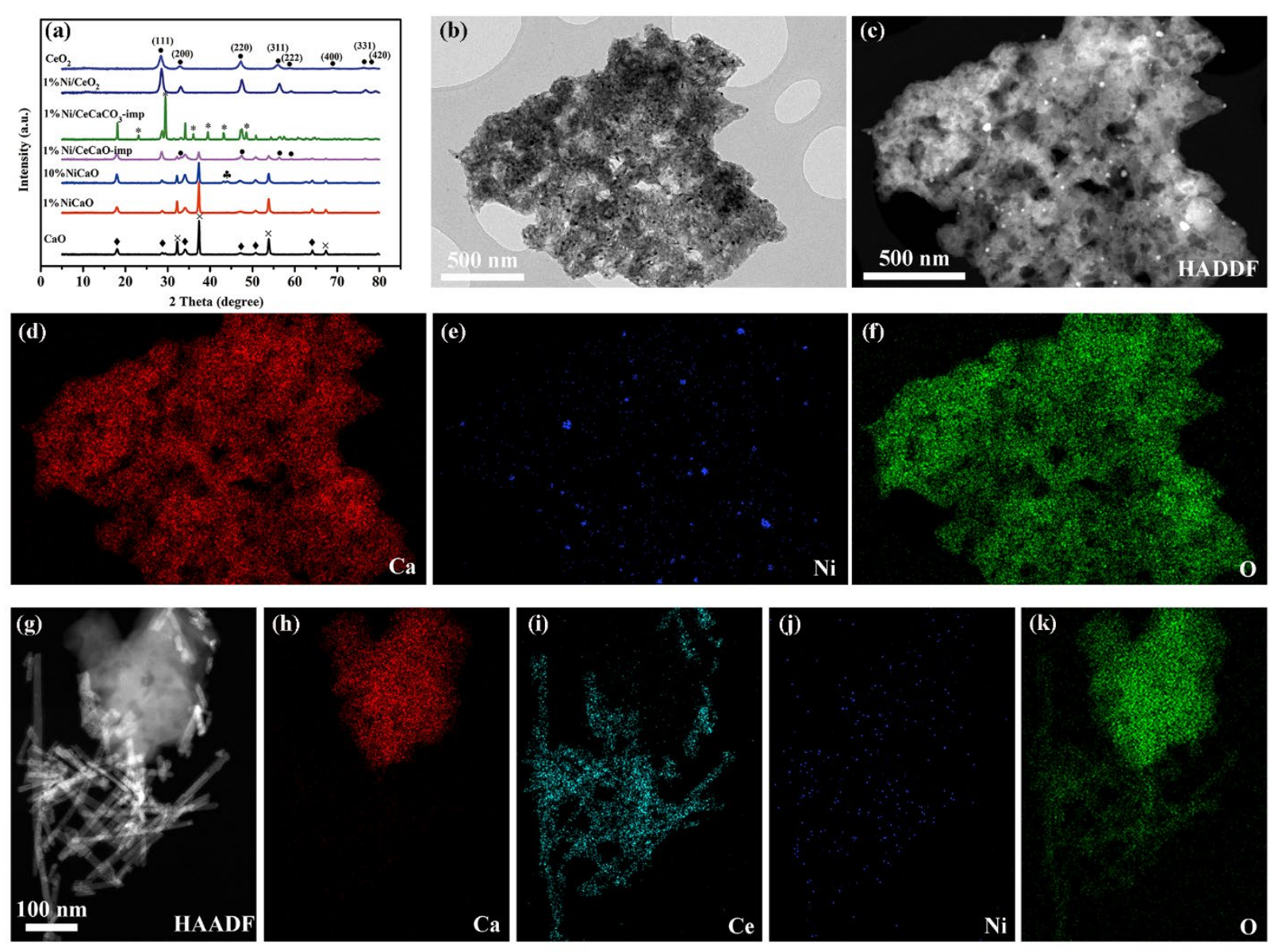
Fig. 1. (a) XRD patterns of sol-gel $\mathrm{CaO}$, pristine $\mathrm{CeO}_{2}$ nanorods and various $\mathrm{DFMs}(\times$ : $\mathrm{CaO} ; \diamond$ :

$\mathrm{Ca}(\mathrm{OH})_{2} ; \bullet: \mathrm{CeO}_{2} ;$ *: $\mathrm{CaCO}_{3}$; $\boldsymbol{2}: \mathrm{Ni}$ ); HAADF-STEM images and EDX elemental mappings of (bf) $1 \% \mathrm{NiCaO}$ and $(\mathrm{g}-\mathrm{k}) 1 \% \mathrm{Ni} / \mathrm{CeO}_{2}-\mathrm{CaO}-$ phy.

The XRD patterns of sol-gel $\mathrm{CaO}$, pristine $\mathrm{CeO}_{2}$ nanorods and various DFMs with different porous structures are displayed in Fig. 1 . The diffraction peaks centred at $32.1^{\circ}, 37.3^{\circ}, 53.8^{\circ}$, and $67.4^{\circ}$ are attributed to the cubic structure of $\mathrm{CaO}$ with space group Fm-3m [26]. The diffraction peaks centred at $18.8^{\circ}, 28.7^{\circ}, 34.1^{\circ}, 47.1^{\circ}, 50.8^{\circ}, 54.4^{\circ}, 59.4^{\circ}, 62.6^{\circ}, 64.2^{\circ}$, and $71.8^{\circ}$ are assigned to the hexagonal structure of $\mathrm{Ca}(\mathrm{OH})_{2}$ with space group P-3ml [27]. Thus, the CaO-based sorbent used in the ICCU process is a mixture of $\mathrm{CaO}$ and $\mathrm{Ca}(\mathrm{OH})_{2}$. Both phases exhibit an increase of volume during the carbonation reaction due to the fact that the volume of $\mathrm{CaCO}_{3}$ is larger than that of both $\mathrm{CaO}$ and $\mathrm{Ca}(\mathrm{OH})_{2}$. As for $1 \% \mathrm{NiCaO}$, no distinct diffraction peaks attributed to $\mathrm{Ni}$ or $\mathrm{NiO}$ are observed in Fig. 1. However, we confirm that $\mathrm{Ni}$ had been successfully introduced in porous $\mathrm{CaO}$ as shown in the HAADF-STEM results (Fig. $1 \mathrm{~b}$ and c), which is in agreement with the uniform distribution of Ni in EDX elemental mapping as shown in Fig 2e. In addition, it is obvious that the $1 \% \mathrm{NiCaO}$ displays a short distance between active sites and sorbents sites. With the increase of Ni loading, a diffraction peak centred at $44.3^{\circ}$ attributed to $\mathrm{Ni}$ is detected in the $10 \% \mathrm{NiCaO}$ due to a bigger particle size as shown in Fig. S3. For the samples with the introduction of Ce, the diffraction peaks at $28.5^{\circ}, 33.2^{\circ}$, $47.6^{\circ}, 56.5^{\circ}, 59.2^{\circ}, 69.4^{\circ}, 76.7^{\circ}$ and $79.1^{\circ}$ are assigned to $\mathrm{CeO}_{2}[28]$. It is found that $\mathrm{Ce}$ acts as a physical barrier to provide a longer distance than one-pot method synthesised DFMs (Fig. S4). For $1 \% \mathrm{Ni} / \mathrm{CeCaCO}_{3}$-imp, sharp peaks centred at $23.1^{\circ}, 29.4^{\circ}, 36.1^{\circ}, 39.5^{\circ}, 43.2^{\circ}$ and $48.7^{\circ}$ are assigned to $\mathrm{CaCO}_{3}$. Even though no peaks belonging to $\mathrm{Ni}$ or $\mathrm{NiO}$ can be observed in $1 \% \mathrm{Ni} / \mathrm{CeO}_{2}$, the HAADF-STEM images and EDX elemental mappings as shown in Fig 2g-k indicates that Ni species are well dispersed on the surface of the $\mathrm{CeO}_{2}$ nanorods [29]. Compared to $1 \% \mathrm{NiCaO}$ and 
$1 \% \mathrm{Ni} / \mathrm{CeCaO}-\mathrm{imp}$, a longer distance of $1 \% \mathrm{Ni} / \mathrm{CeO}_{2}-\mathrm{CaO}$-phy can be observed in Fig. 1g. Therefore, it is confirmed that $1 \% \mathrm{NiCaO}, 10 \% \mathrm{NiCaO}, 1 \% \mathrm{Ni} / \mathrm{CeCaO}-\mathrm{imp}, 1 \% \mathrm{Ni} / \mathrm{CeCaCO}_{3}-\mathrm{imp}$ and $1 \% \mathrm{Ni} / \mathrm{CeO}_{2}-\mathrm{CaO}$-phy consist of $\mathrm{CaO}$ and $\mathrm{Ni}$ acting as the sorbent and active sites, respectively.

\subsection{ICCU performance of DFMs synthesized by one-pot method}

The ICCU performance including product distribution, carbon balance, $\mathrm{CO}_{2}$ conversion and $\mathrm{CH}_{4}$ selectivity of various DFMs with different distances between active sites and sorbents is presented in Fig. 2 and Table 2. The pristine $\mathrm{CeO}_{2}$ nanorods demonstrate a carbon capture capacity due to their basic property as reported in the previous literature $[28,30]$. However, both $\mathrm{CH}_{4}$ and $\mathrm{CO}$ cannot be detected indicating the ICCU process cannot occur in a single reactor at the same temperature (550 ${ }^{\circ} \mathrm{C}$ ) using $\mathrm{CeO}_{2}$ as both the sorbent and catalyst. When the DFMs are a physical mixture of $\mathrm{CeO}_{2}$ nanorod and $\mathrm{CaO}$, the capacity of carbon capture is greatly increased to $14.94 \mathrm{mmol} \mathrm{g}^{-1}$. However, no $\mathrm{CH}_{4}$ is observed after switching the feed gas to $\mathrm{H}_{2}$ as shown in Fig. 2a due to the absence of Ni active sites. $\mathrm{CO}$ is the main product using the above DFMs; this might be because oxygen vacancies in the $\mathrm{CeO}_{2}$ could directly reduce $\mathrm{CO}_{2}$ to form $\mathrm{CO}[15,31]$. In addition, $\mathrm{CaO}-\mathrm{CeO}_{2}$ exhibits a relatively low carbon balance (48\%) and $\mathrm{CO}_{2}$ conversion $(39 \%)$ as shown in Fig. 2 b indicating more captured $\mathrm{CO}_{2}$ is in the form of $\mathrm{CaCO}_{3}$ (not converted during the utilization stage). This is further confirmed by the $\mathrm{CaCO}_{3}$ diffraction peaks centred at $29.4^{\circ}, 39.4^{\circ}$ and $48.4^{\circ}$ in the XRD results as shown in Fig. 2c. 
(a)

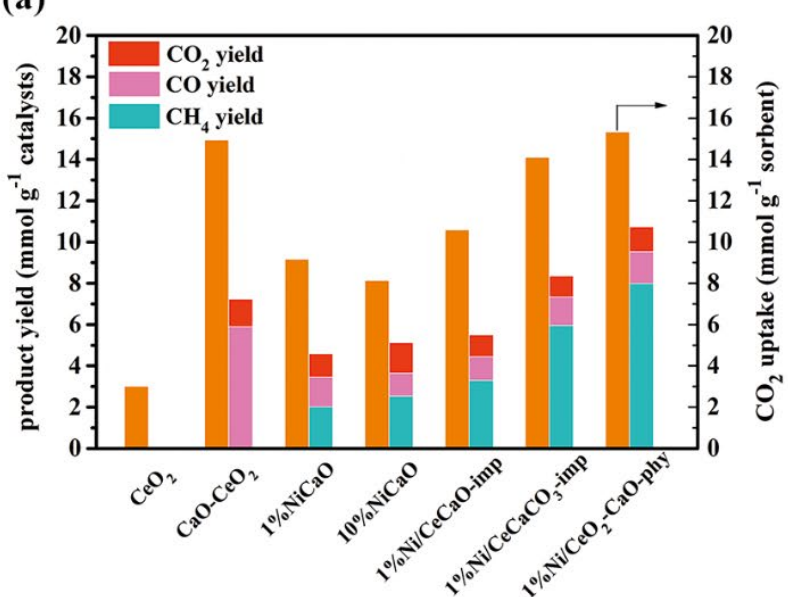

(c)

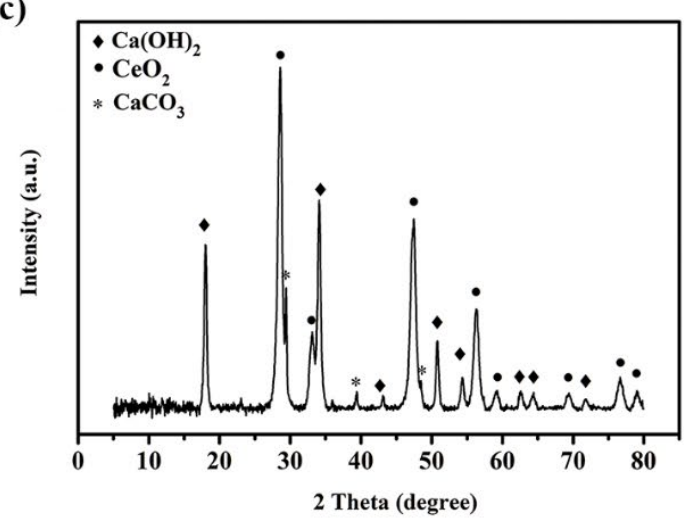

(e)

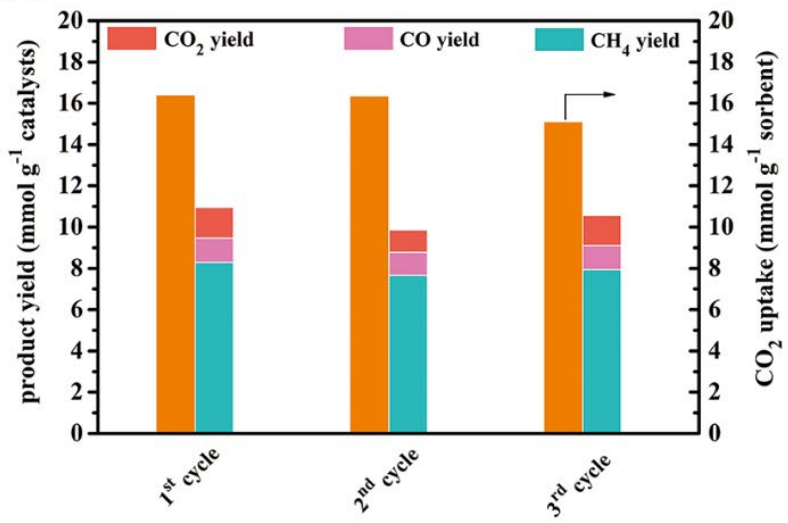

(b)
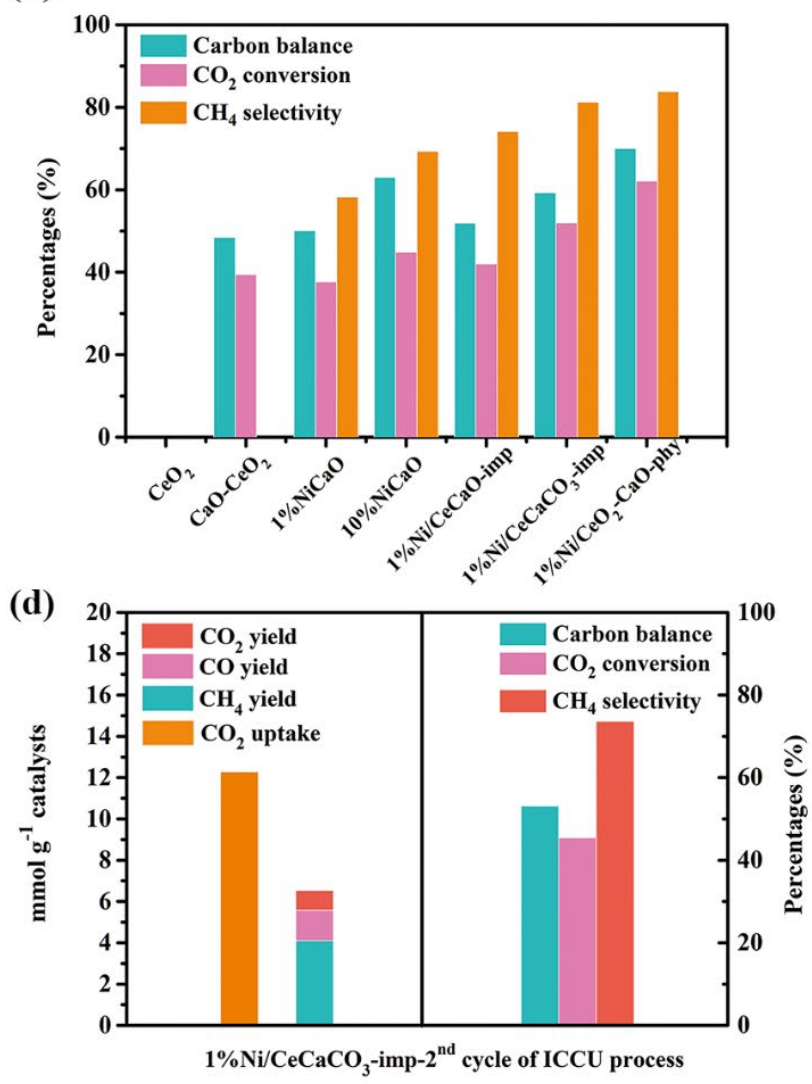

(f)

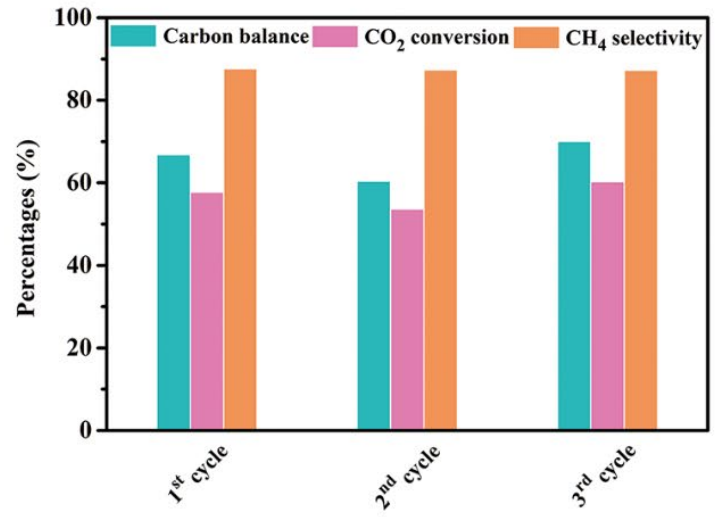

Fig. 2. (a) Product distribution; (b) carbon balance, $\mathrm{CO}_{2}$ conversion and $\mathrm{CH}_{4}$ selectivity for ICCU performance; (c) XRD patterns of spent $\mathrm{CaO}-\mathrm{CeO}_{2}$ after 1 cycle of ICCU process; (d) the $2^{\text {nd }}$ cycle ICCU performance of $1 \% \mathrm{Ni} / \mathrm{CeCaCO}_{3}$-imp; (e) Product distribution; (f) carbon balance, $\mathrm{CO}_{2}$ conversion and $\mathrm{CH}_{4}$ selectivity for 3 cycles ICCU performance of $1 \% \mathrm{Ni} / \mathrm{CeO}_{2}-\mathrm{CaO}$-phy. 
When using the one-pot method synthesized $1 \% \mathrm{NiCaO}$ as the DFMs, the carbon capture capacity is $9.16 \mathrm{mmol} \mathrm{g}^{-1}$. However, the $\mathrm{CH}_{4}$ yield and $\mathrm{CO}_{2}$ conversion are only $2.0 \mathrm{mmol} \mathrm{g}^{-1}$ and $38 \%$, respectively. The $\mathrm{CH}_{4}$ selectivity reaches $58 \%$ indicating that the introduction of $\mathrm{Ni}$ species is efficient for hydrogen dissociation [32, 33]. With the further increase of Ni loading to 10 wt.\% $(10 \% \mathrm{NiCaO})$, the $\mathrm{CH}_{4}$ yield is slightly increased from $2.0 \mathrm{mmol} \mathrm{g}^{-1}$ to $2.5 \mathrm{mmol} \mathrm{g}$. $\mathrm{The}^{-\mathrm{CO}_{2}}$ conversion and $\mathrm{CH}_{4}$ selectivity are also slightly increased to $45 \%$ and $69 \%$, respectively. A large amount of captured $\mathrm{CO}_{2}$ remains in the DFMs in the form of $\mathrm{CaCO}_{3}$, which is proved by the XRD results in Fig. S5. This is surprising, as the increase of Ni loading is known to significantly enhance $\mathrm{CH}_{4}$ production from $\mathrm{CO}_{2}$ hydrogenation [33]. This might be because the volume of $\mathrm{CaCO}_{3}$ is 34.1 $\mathrm{cm}^{3} \mathrm{~mol}^{-1}$, which is much larger than that of $\mathrm{CaO}\left(16.9 \mathrm{~cm}^{3} \mathrm{~mol}^{-1}\right)[6,34]$. For the DFMs synthesized by a one-pot method, the expansion of the sorbent after carbonation reaction results in two main structural changes. On one hand, the pores of DFMs will be filled. On the other hand, the Ni active sites could be covered by the formed $\mathrm{CaCO}_{3}$ layer. This is further confirmed by the Ni dispersion decreasing from $1.66 \%$ and $0.23 \%$ to $0.23 \%$ and $0.07 \%$ in $1 \% \mathrm{NiCaO}$ and $10 \% \mathrm{NiCaO}$, respectively (Table 2).

\subsection{ICCU performance of DFMs synthesized by wet impregnation}

It is suggested that a short distance between sorbents and active sites in the one-pot synthesized $\mathrm{Ni} / \mathrm{CaO}$ will cover the catalytic $\mathrm{Ni}$ sites after the carbonation stage. We prepared Ni-based catalyst by impregnating Ni sites on the support, resulting in longer distance than the one-pot reduced catalysts. As a result, the $\mathrm{CH}_{4}$ yield of $1 \% \mathrm{Ni} / \mathrm{CeCaO}$-imp synthesized by the wet impregnation method is increased to $3.3 \mathrm{mmol} \mathrm{g}^{-1}$. This could also be attributed to the introduction of $\mathrm{CeO}_{2}$ acting as a physical 
barrier between active sites and sorbents mitigating the influence of molar volume increase of $\mathrm{CaO}$ during the carbonation stage $[35,36]$.

To further prove the negative influence of molar volume growth of $\mathrm{CaO}$ on $\mathrm{CH}_{4}$ production in the ICCU process, we directly compared two DFMs consisting of $\mathrm{Ni}, \mathrm{Ce}$ and $\mathrm{Ca}$ using $1 \% \mathrm{Ni} / \mathrm{CeCaO}-$ imp and $1 \% \mathrm{Ni} / \mathrm{CeCaCO}_{3}$-imp. The sorbent of $\mathrm{DFM}, \mathrm{CeCaO}$, was carbonized prior to the impregnation of $\mathrm{Ni}$ active sites. In this case, the prepared catalyst, $1 \% \mathrm{Ni} / \mathrm{CeCaCO}_{3}$-imp, has most of the $\mathrm{Ni}$ active sites outside of the sorbents. While for the $1 \% \mathrm{Ni} / \mathrm{CeCaO}-\mathrm{imp} \mathrm{DFM}$, after carbonation, active $\mathrm{Ni}$ sites could be largely covered by $\mathrm{CaCO}_{3}$. The $\mathrm{Ni}$ dispersion of $1 \% \mathrm{Ni} / \mathrm{CeCaO}$-imp decreases from $0.82 \%$ to $0.21 \%$ after carbonation reaction (Table 2 ). As expected, $\mathrm{CH}_{4}$ yield and $\mathrm{CH}_{4}$ selectivity were largely increased to $6.0 \mathrm{mmol} \mathrm{g}^{-1}$ and $81 \%$, respectively, for the $1 \% \mathrm{Ni} / \mathrm{CeCaCO}_{3}$-imp $\mathrm{DFM}$, because the $\mathrm{Ni}$ active sites are not covered by $\mathrm{CaCO}_{3}$. It is consistent with that only a slight change of $\mathrm{Ni}$ dispersion before $(0.61 \%)$ and after carbonation reaction $(0.51 \%)$. However, after $2^{\text {nd }}$ cycle of ICCU using this DFM $\left(1 \% \mathrm{Ni} / \mathrm{CeCaCO}_{3}\right.$-imp), $\mathrm{CH}_{4}$ yield and $\mathrm{CH}_{4}$ selectivity are decreased to 4.11 mmol $\mathrm{g}^{-1}$ and $74 \%$, respectively as shown in Fig. $2 \mathrm{~d}$. This is because during the utilization stage of the $1^{\text {st }}$ cycle, $\mathrm{CaCO}_{3}$ was decomposed to $\mathrm{CaO}$, which was carbonized at the $2^{\text {nd }} \mathrm{CO}_{2}$ capture stage, and covered $\mathrm{Ni}$ active sites at the $2^{\text {nd }}$ cycle due to the molar volume change.

Table 2 ICCU performance of various DFMs. 


\begin{tabular}{|c|c|c|c|c|c|c|c|}
\hline Samples & $\begin{array}{c}\mathrm{CO}_{2} \text { capture } \\
\text { capacity } \\
\left(\mathrm{mmol} \mathrm{g}^{-1}\right)\end{array}$ & $\begin{array}{l}\mathrm{CH}_{4} \text { yield } \\
\left(\mathrm{mmol} \mathrm{g}^{-1}\right)\end{array}$ & $\begin{array}{c}\mathrm{CO}_{2} \\
\text { conversion } \\
(\%)\end{array}$ & $\begin{array}{c}\mathrm{CH}_{4} \\
\text { selectivity } \\
(\%)\end{array}$ & $\begin{array}{c}\mathrm{Ni} \\
\text { dispersion }^{\mathrm{a}} \\
(\%)\end{array}$ & $\begin{array}{c}\mathrm{Ni} \\
\text { dispersion }^{\mathrm{b}} \\
(\%)\end{array}$ & $\begin{array}{l}\mathrm{TOF}^{\mathrm{c}} \\
\left(\mathrm{s}^{-1}\right)\end{array}$ \\
\hline $\mathrm{CaO}-\mathrm{CeO}_{2}$ & 14.9 & 0 & 39 & 0.00 & l & l & l \\
\hline $1 \% \mathrm{NiCaO}$ & 9.2 & 2.0 & 38 & 58 & 1.66 & 0.23 & 2.4 \\
\hline $10 \% \mathrm{NiCaO}$ & 8.1 & 2.5 & 45 & 69 & 0.23 & 0.07 & 0.9 \\
\hline $1 \% \mathrm{Ni} / \mathrm{CeCaO}-\mathrm{imp}$ & 10.6 & 3.3 & 42 & 74 & 0.82 & 0.21 & 3.0 \\
\hline $1 \% \mathrm{Ni} / \mathrm{CeCaCO}_{3}$-imp & 14.1 & 6.0 & 52 & 81 & 0.61 & 0.51 & 2.0 \\
\hline $1 \% \mathrm{Ni} / \mathrm{CeO}_{2}-\mathrm{CaO}-$ phy & 15.3 & 8.0 & 62 & 84 & 0.82 & 0.86 & 3.6 \\
\hline
\end{tabular}

${ }^{\text {a }} \mathrm{Ni}$ dispersion before $1^{\text {st }}$ stage (carbonation reaction) of ICCU process.

${ }^{\mathrm{b}} \mathrm{Ni}$ dispersion after $1^{\text {st }}$ stage (carbonation reaction) of ICCU process.

${ }^{\mathrm{c}} \mathrm{TOF}=$ Number of moles of reactant consumed/(number of active centres*reaction time).

Number of active centres=the weight of catalysts*metal loading*Ni dispersion/Ni relative atomic mass

$\underline{\text { Reaction time }=60 \mathrm{mins}}$

We further evaluate the interactions between catalytic sites and sorbents at the molecular level using FIB-SEM/EDX methods. The cross-section images and Ni concentrations across the particles are conducted to study the porous structure and element distribution of both the fresh and spent DFMs synthesized by wet impregnation method as displayed in Fig. 3. Through the comparison of Fig. 3a and Fig. 3d, no large changes can be observed in the porous structure between the fresh and spent $1 \% \mathrm{Ni} / \mathrm{CeCaO}-i m p$. The $\mathrm{Ni}$ concentration of fresh $1 \% \mathrm{Ni} / \mathrm{CeCaO}$-imp as shown in Fig. $3 \mathrm{~b}$ and $\mathrm{c}$ is gradually decreased from the surface to the internal area indicating that the wet impregnation method is a process of infiltration from the outside to the inside. However, the surface Ni concentration of spent $1 \% \mathrm{Ni} / \mathrm{CeCaO}-\mathrm{imp}$ is much lower than that of fresh $1 \% \mathrm{Ni} / \mathrm{CeCaO}$-imp due to the surface $\mathrm{Ni}$ species which were covered by the $\mathrm{CaCO}_{3}$ formed during the carbonation reaction. An obvious 
change of porous structure is displayed in Fig. $3 \mathrm{~g}$ and j. $1 \% \mathrm{Ni} / \mathrm{CeCaCO}_{3}-\mathrm{imp}$ as shown in Fig. $3 \mathrm{c}$ demonstrates a bulk structure because the porous structure of $\mathrm{Ce}$ doped sol-gel $\mathrm{CaO}$ has been filled by $\mathrm{CaCO}_{3}$ after the carbonation reaction at $550{ }^{\circ} \mathrm{C}$ for 60 min during the sample preparation. After impregnating $\mathrm{Ni}$ on $\mathrm{CeCaCO}_{3}$, the surface of $1 \% \mathrm{Ni} / \mathrm{CeCaCO}_{3}$-imp exhibited a high $\mathrm{Ni}$ concentration as shown in Fig. $3 \mathrm{~h}$ and $\mathrm{i}$. The surface $\mathrm{Ni}$ concentration of spent $1 \% \mathrm{Ni} / \mathrm{CeCaCO}_{3}$-imp after the $1^{\text {st }}$ cycle of the ICCU process is further increased compared to fresh $1 \% \mathrm{Ni} / \mathrm{CeCaCO}_{3}-\mathrm{imp}$. This is attributed to the suggestion that $\mathrm{CaCO}_{3}$ species on the surface of spent $1 \% \mathrm{Ni} / \mathrm{CeCaCO}_{3}$-imp are consumed through the ICCU process. 

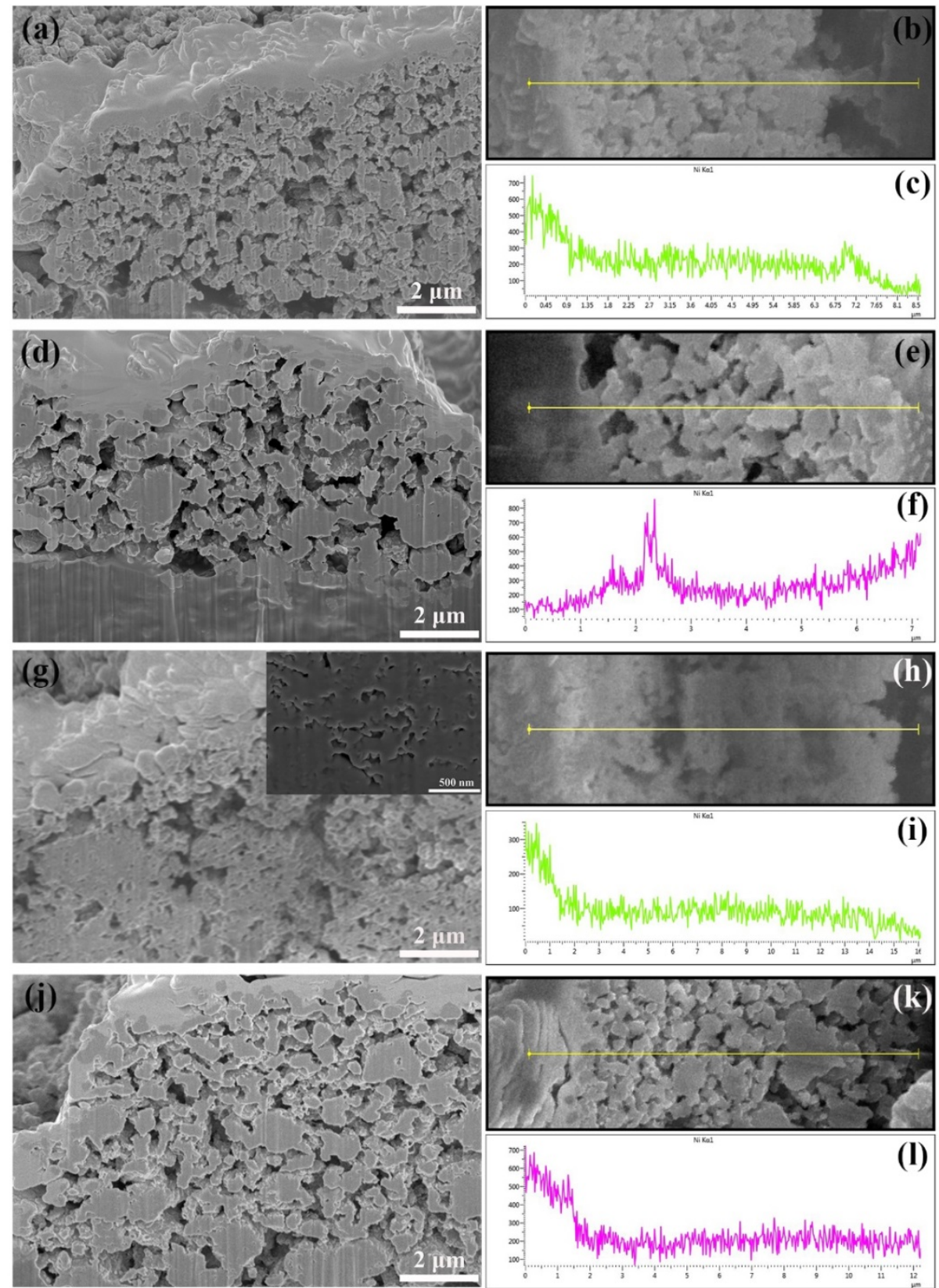

Fig. 3. FIB-SEM/EDX images of various DFMs: (a-c) fresh $1 \% \mathrm{Ni} / \mathrm{CeCaO}-\mathrm{imp}$; (d-f) spent $1 \% \mathrm{Ni} / \mathrm{CeCaO}-\mathrm{imp}$; (g-i) fresh $1 \% \mathrm{Ni} / \mathrm{CeCaCO}_{3}$-imp, (j-1) spent $1 \mathrm{Ni} / \mathrm{CeCaCO}_{3}$-imp.

\subsection{ICCU performance of DFMs synthesized by physical mixing}

As the previous developed $1 \% \mathrm{Ni} / \mathrm{CeCaCO}_{3}$-imp cannot mitigate the negative influence of molar volume increase on the coverage of Ni sites, we developed DFMs using a physical mixing method.

By physically mixing $1 \% \mathrm{Ni} / \mathrm{CeO}_{2}$ catalyst with $\mathrm{CaO}$, the yield of $\mathrm{CH}_{4}$ is significantly increased to 
$8.0 \mathrm{mmol} \mathrm{g}{ }^{-1}$ due to the longer distance between active sites and sorbents compared to $1 \% \mathrm{NiCaO}$, $10 \% \mathrm{NiCaO}$ and $1 \% \mathrm{Ni} / \mathrm{CeCaO}$-imp as shown in Fig. 1. Thus, the $\mathrm{Ni}$ active sites are still exposed on $\mathrm{CeO}_{2}$ nanorods after carbonation reaction instead of being covered by the newly formed $\mathrm{CaCO}_{3}$, which is consistent with the comparable Ni dispersion of fresh $(0.82 \%)$ and carbonated DFMs $(0.86 \%)$ (Table 2). Therefore, $1 \% \mathrm{Ni} / \mathrm{CeO}_{2}-\mathrm{CaO}$-phy exhibits the highest carbon balance $(70 \%), \mathrm{CO}_{2}$ conversion (62\%) as well as the highest $\mathrm{CH}_{4}$ selectivity (84\%). The highest TOF number $\left(3.6 \mathrm{~s}^{-1}\right)$ further indicates the better catalytic performance of $1 \% \mathrm{Ni} / \mathrm{CeO}_{2}-\mathrm{CaO}-$ phy. In addition, the $1 \% \mathrm{Ni} / \mathrm{CeO}_{2}-\mathrm{CaO}-$ phy DFM shows a good stability after 3 cycles of ICCU as shown in Fig. $2 \mathrm{~d}$ and $\mathrm{f}$. It is proposed that the distance between $\mathrm{Ni}$ sites and sorbents in the physical mixed DFMs is sufficient to mitigate the problem of $\mathrm{Ni}$ coverage after the $\mathrm{CO}_{2}$ capture stage. In addition, $\mathrm{CeO}_{2}$ nanorods improve the dispersion of Ni species, and act as a support to prevent the sintering of Ni species [37, 38].

In addition, in-situ $\mathrm{XRD}$ patterns of $10 \% \mathrm{NiCaO}$ and $10 \% \mathrm{Ni} / \mathrm{CeO}_{2}-\mathrm{CaO}$-phy were conducted to reveal the phase changes during the carbonation reaction. As shown in Fig. 4, the peaks assigned to $\mathrm{CaCO}_{3}$ and $\mathrm{NiO}$ were largely increased, while the peak attributed to $\mathrm{Ni}$ was gradually disappeared during the carbonation reaction. We use $10 \% \mathrm{Ni} / \mathrm{CeO}_{2}-\mathrm{CaO}-$ phy for the in-situ $\mathrm{XRD}$ due to a high loading of $\mathrm{Ni}$ is easier to be detected. However, only $\mathrm{NiO}$ peak can be observed in the XRD patterns. During the $2^{\text {nd }}$ stage of ICCU process, $\mathrm{NiO}$ will be reduced by $\mathrm{H}_{2}$ firstly for both $10 \% \mathrm{NiCaO}$ and $10 \% \mathrm{Ni} / \mathrm{CeO}_{2}$ CaO-phy, which can be confirmed by Ni peak centered at $44.3^{\circ}$ in XRD results (Fig. S5 and Fig. S6). As for $10 \% \mathrm{NiCaO}$, most of the $\mathrm{NiO}$ was covered by the formed $\mathrm{CaCO}_{3}$. Only small amount of $\mathrm{NiO}$ was reduced to $\mathrm{Ni}$. Therefore, limited $\mathrm{CaCO}_{3}$ reacted with the dissociated $\mathrm{Ni}$ and produced slight $\mathrm{CH}_{4}$. However, the reduced $\mathrm{Ni}$ species are well dispersed on $\mathrm{CeO}_{2}$ nanorods in $1 \% \mathrm{Ni} / \mathrm{CeO}_{2}-\mathrm{CaO}$. The ICCU performance was largely enhanced. 

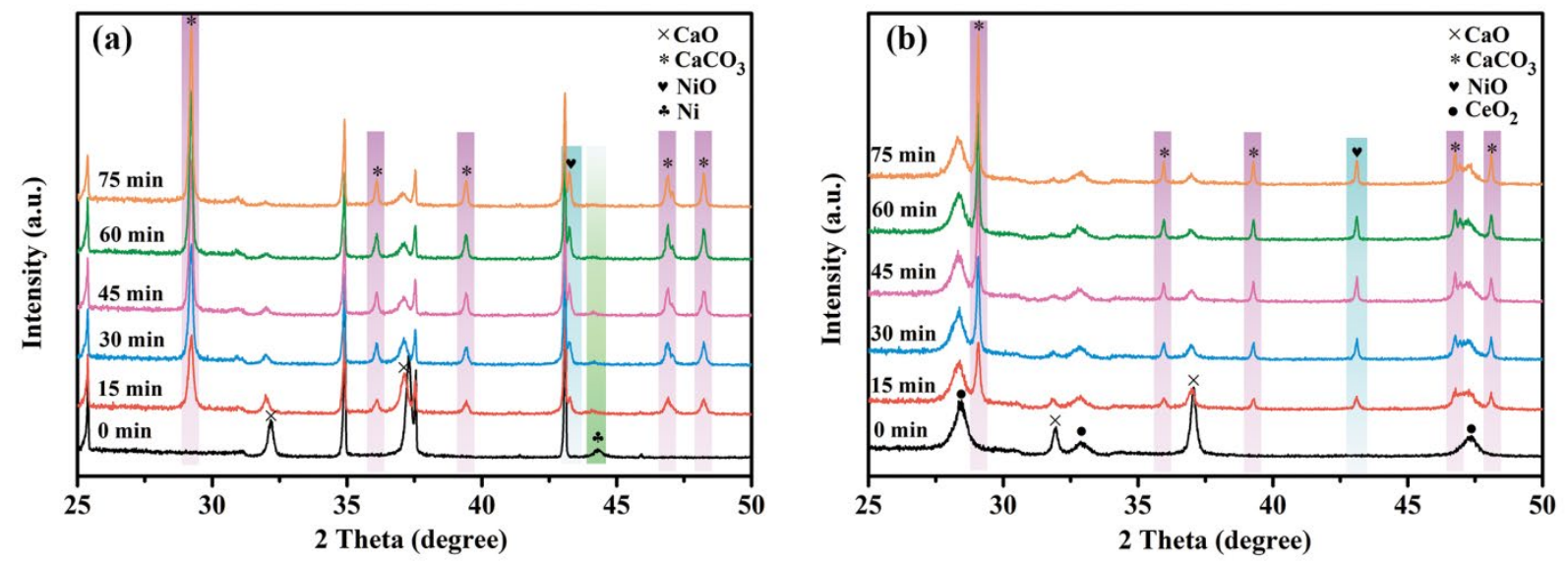

Fig. 4. In-situ $\mathrm{XRD}$ patterns of (a) $10 \% \mathrm{NiCaO}$ and (b) $10 \% \mathrm{Ni} / \mathrm{CeO}_{2}-\mathrm{CaO}$-phy during the carbonation reaction.

Based on the experimental results discussed in this work, a mechanism for the enhancement of ICCU process by $1 \% \mathrm{Ni} / \mathrm{CeO}_{2}-\mathrm{CaO}$-phy DFMs is proposed as shown in Fig. 5. For the one-pot synthesized $1 \% \mathrm{NiCaO}$, the $\mathrm{Ni}$ active sites will be covered by formed $\mathrm{CaCO}_{3}$ layer after carbonation reaction as shown in Fig. $5 \mathrm{a}$ because the volume increase from $\mathrm{CaO}$ to $\mathrm{CaCO}_{3}$. Therefore, $1 \% \mathrm{NiCaO}$ exhibited a low $\mathrm{CO}_{2}$ conversion and $\mathrm{CH}_{4}$ selectivity. However, the ICCU performance of $1 \% \mathrm{Ni} / \mathrm{CeO}_{2}-\mathrm{CaO}-$ phy was largely enhanced due to a longer distance between active sites and sorbents. The Ni active sites were still well dispersed on the surface of $\mathrm{CeO}_{2}$ nanorods after carbonation reaction as shown in Fig. 5b. 
(a)
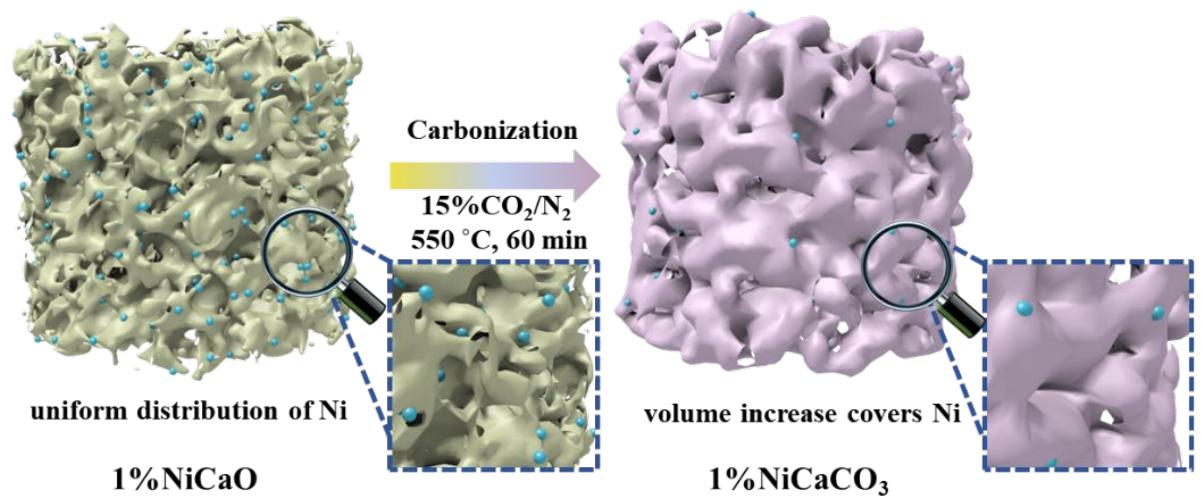

(b)

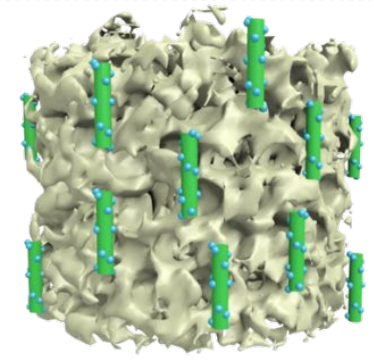

$1 \% \mathrm{Ni} / \mathrm{CeO}_{2}-\mathrm{CaO}-\mathrm{phy}$

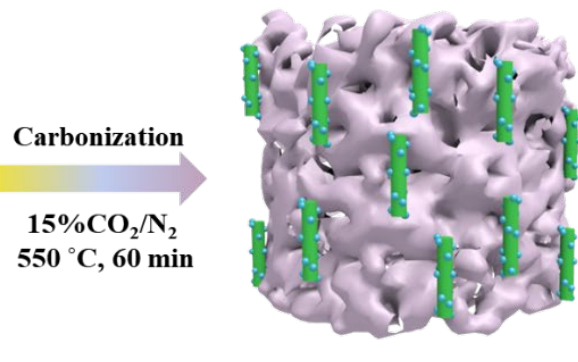

$1 \% \mathrm{Ni} / \mathrm{CeO}_{2}-\mathrm{CaCO}_{3}-\mathrm{phy}$
Note: uniform distribution of $\mathrm{Ni}$ active sites after carbonation due to the longer distance between catalytic and sorbent sites.

Fig. 5. Proposed mechanism for the enhancement of ICCU process by $1 \% \mathrm{Ni} / \mathrm{CeO}_{2}-\mathrm{CaO}-$ phy DFMs.

\section{Conclusions}

The ICCU process which is a combination of carbon capture and $\mathrm{CO}_{2}$ methanation at $550{ }^{\circ} \mathrm{C}$ using $\mathrm{Ni} / \mathrm{CaO}$-based DFMs is proposed in this study. We further investigate the interaction between the volume increase of sorbents after the carbonation reaction and the accessibility of $\mathrm{Ni}$ active sites in the $\mathrm{CO}_{2}$ conversion using various DFMs with different distances between active sites and sorbents. Compared to $1 \% \mathrm{NiCaO}\left(\mathrm{CO}_{2}\right.$ conversion and $\mathrm{CH}_{4}$ selectivity are $38 \%$ and $58 \%$, respectively), $10 \% \mathrm{NiCaO}$ still exhibited a low $\mathrm{CO}_{2}$ conversion of $45 \%$ and $\mathrm{CH}_{4}$ selectivity of $69 \%$ due to the dramatic volume increase from $\mathrm{CaO}$ to $\mathrm{CaCO}_{3}$ after the carbonation reaction. Thus, the Ni active sites in DFMs synthesized by the one-pot method were covered by the formed $\mathrm{CaCO}_{3}$ due to the short distance between acitve sites and sorbents. When the DFMs were prepared by the physical mixing of $\mathrm{CaO}$ sorbent and $\mathrm{Ni} / \mathrm{CeO}_{2}$ catalyst, $1 \% \mathrm{Ni} / \mathrm{CeO}_{2}-\mathrm{CaO}$-phy exhibited a much better ICCU performance including a much higher $\mathrm{CO}_{2}$ conversion (62\%) and $\mathrm{CH}_{4}$ selectivity $(84 \%)$ as well as a higher $\mathrm{CH}_{4}$ 
yield $\left(8.0 \mathrm{mmol} \mathrm{g}^{-1}\right)$. It is suggested that the $\mathrm{Ni}$ active sites are still exposed on the surface of $\mathrm{CeO}_{2}$ nanorods instead of being covered by the newly formed $\mathrm{CaCO}_{3}$ after the carbonation reaction. Therefore, understanding the interaction between active sties and sorbents is essential to synthesize effective DFMs for ICCU process.

\section{CRediT authorship contribution statement}

H. Sun: Conceptualization, Investigation, Visualization, Formal analysis, Writing-original draft. Y. Wang: Conceptualization, Formal analysis, Writing-review \& editing. S. Xu, A. I. Osman and J. Han: Investigation, Writing-review \& editing. S. Sun: Investigation, Visualization. D. Rooney: Investigation, Writing-review \& editing, P. T. Williams: Investigation, Visualization, Writingreview \& editing. F. Wang: Supervision, Conceptualization, Writing-review \& editing. C. Wu: Supervision, Conceptualization, Writing-review \& editing

\section{Conflicts of interest}

There are no conflicts to declare.

\section{Acknowledgements}

The authors acknowledge the funding from the European Union's Horizon 2020 research and innovation programme under the Marie Skłodowska-Curie Grant Agreement (No. 823745). Hongman Sun thanks the financial support from the China Scholarship Council (No. 201606450016). We would like to thank Gavin Stenning for help on the XRD instrument in the Materials Characterisation Laboratory at the ISIS Neutron and Muon Source. 


\section{References}

[1] Liu L, Das S, Chen T, et al. Low temperature catalytic reverse water-gas shift reaction over perovskite catalysts in DBD plasma. Appl Catal B: Environ 2020;265:118573.

[2] $\mathrm{Hu}$ Y, Liu X, Zhou Z, et al. Pelletization of MgO-based sorbents for intermediate temperature $\mathrm{CO}_{2}$ capture. Fuel 2017;187:328-37.

[3] Erans M, Manovic V, Anthony E J. Calcium looping sorbents for $\mathrm{CO}_{2}$ capture. Appl Energy 2016;180:722-42.

[4] Gao N, Chen K, Quan C. Development of CaO-based adsorbents loaded on charcoal for $\mathrm{CO}_{2}$ capture at high temperature. Fuel 2020;260:116411.

[5] Perejón A, Romeo L M, Lara Y, et al. The calcium-looping technology for $\mathrm{CO}_{2}$ capture: on the important roles of energy integration and sorbent behavior. Appl Energy 2016;162:787-807.

[6] Sun H, Wu C, Shen B, et al. Progress in the development and application of CaO-based adsorbents for $\mathrm{CO}_{2}$ capture-a review. Mater Today Sustain 2018;1:1-27.

[7] Ridha F N, Lu D Y, Symonds R T, et al. Attrition of CaO-based pellets in a 0.1 MWth dual fluidized bed pilot plant for post-combustion $\mathrm{CO}_{2}$ capture. Powder Technol 2016;291:60-65.

[8] Bravo P M, Debecker D P. Combining $\mathrm{CO}_{2}$ capture and catalytic conversion to methane. Waste Disposal \& Sustainable Energy 2019;1:53-65.

[9] Proaño L, Tello E, Arellano-Trevino M A, et al. In-situ DRIFTS study of two-step $\mathrm{CO}_{2}$ capture and catalytic methanation over $\mathrm{Ru}, " \mathrm{Na}_{2} \mathrm{O}$ "/ $/ \mathrm{Al}_{2} \mathrm{O}_{3}$ Dual Functional Material. Appl Surf Sci 2019;479:25-30.

[10] Bermejo-López A, Pereda-Ayo B, González-Marcos J A, et al. Mechanism of the $\mathrm{CO}_{2}$ storage and in situ hydrogenation to $\mathrm{CH}_{4}$. Temperature and adsorbent loading effects over $\mathrm{Ru}-\mathrm{CaO} / \mathrm{Al}_{2} \mathrm{O}_{3}$ and $\mathrm{Ru}-\mathrm{Na}_{2} \mathrm{CO}_{3} / \mathrm{Al}_{2} \mathrm{O}_{3}$ catalysts. Appl Catal B: Environ 2019;256:117845.

[11] Duyar M S, Wang S, Arellano Trevino M A, et al. $\mathrm{CO}_{2}$ utilization with a novel dual function material (DFM) for capture and catalytic conversion to synthetic natural gas: An update. J CO2 Util 2016;15:65-71.

[12] Arellano-Treviño M A, Kanani N, Jeong-Potter C W, et al. Bimetallic catalysts for $\mathrm{CO}_{2}$ capture 
and hydrogenation at simulated flue gas conditions. Chem Eng J 2019;121953.

[13] Sun H, Zhang Y, Guan S, et al. Direct and highly selective conversion of captured $\mathrm{CO}_{2}$ into methane through integrated carbon capture and utilization over dual functional materials. J CO2 Util 2020;38:262-72.

[14] Sun Z, Sedghkerdar M H, Saayman J, et al. A Facile fabrication of mesoporous core-shell CaOBased pellets with enhanced reactive stability and resistance to attrition in cyclic $\mathrm{CO}_{2}$ capture. J Mater Chem A 2014;2:16577-88.

[15] Sun H, Wang J, Zhao J, et al. Dual functional catalytic materials of Ni over Ce-modified CaO sorbents for integrated $\mathrm{CO}_{2}$ capture and conversion. Appl Catal B: Environ 2019;244:63-75.

[16] Kim S M, Abdala P M, Broda M, et al. Integrated $\mathrm{CO}_{2}$ Capture and Conversion as an Efficient Process for Fuels from Greenhouse Gases. ACS Catal 2018;8:2815-23.

[17] Duyar M S, Trevino M AA, Farrauto R J. Dual function materials for $\mathrm{CO}_{2}$ capture and conversion using renewable $\mathrm{H}_{2}$. Appl Catal B: Environ 2015;168:370-76.

[18] Rodriguez J A, Evans J, Feria L, et al. $\mathrm{CO}_{2}$ hydrogenation on $\mathrm{Au} / \mathrm{TiC}, \mathrm{Cu} / \mathrm{TiC}$, and $\mathrm{Ni} / \mathrm{TiC}$ catalysts: Production of CO, methanol, and methane. J Catal 2013;307:162-69.

[19] Zhen W, Gao F, Tian B, et al. Enhancing activity for carbon dioxide methanation by encapsulating $\left(\begin{array}{lll}1 & 1 & 1\end{array}\right)$ facet Ni particle in metal-organic frameworks at low temperature. J Catal 2017;348:200-11.

[20] Martin N M, Velin P, Skoglundh M, et al. Catalytic hydrogenation of $\mathrm{CO}_{2}$ to methane over supported Pd, Rh and Ni catalysts. Catal Sci Technol 2017;7:1086-94.

[21] Guo Y, Mei S, Yuan K, et al. Low-Temperature $\mathrm{CO}_{2}$ Methanation over $\mathrm{CeO}_{2}-$ Supported $\mathrm{Ru}$ Single Atoms, Nanoclusters, and Nanoparticles Competitively Tuned by Strong Metal-Support Interactions and H-Spillover Effect. ACS Catal 2018;8:6203-15.

[22] Chen C, Budi C S, Wu H, et al. Size-tunable Ni nanoparticles supported on surface-modified, cage-type mesoporous silica as highly active catalysts for $\mathrm{CO}_{2}$ hydrogenation. ACS Catal 2017;7:8367-81.

[23] Solis-Garcia A, Louvier-Hernandez J F, Almendarez-Camarillo A, et al. Participation of surface 
bicarbonate, formate and methoxy species in the carbon dioxide methanation catalyzed by $\mathrm{ZrO}_{2}$ supported Ni. Appl Catal B: Environ 2017;218:611-20.

[24] Liu F, Li W, Liu B, et al. Synthesis, characterization, and high temperature $\mathrm{CO}_{2}$ capture of new $\mathrm{CaO}$ based hollow sphere sorbents. J Mater Chem A 2013;1:8037-44.

[25] Liu B, Li C, Zhang G, et al. Oxygen Vacancy Promoting Dimethyl Carbonate Synthesis from $\mathrm{CO}_{2}$ and Methanol over Zr-Doped $\mathrm{CeO}_{2}$ Nanorods. ACS Catal 2018;8:10446-56.

[26] Sun H, Wang J, Liu X, et al. Fundamental studies of carbon capture using CaO-based materials. J Mater Chem A 2019;7:9977-87.

[27] Kwasny J, Basheer P, Russell M I, et al. $\mathrm{CO}_{2}$ sequestration in cement-based materials during mixing process using carbonated water and gaseous $\mathrm{CO}_{2} .2014$.

[28] Sakpal T, Lefferts L. Structure-dependent activity of $\mathrm{CeO}_{2}$ supported $\mathrm{Ru}$ catalysts for $\mathrm{CO}_{2}$ methanation. J Catal 2018;367:171-80.

[29] Wang F, Li C, Zhang X, et al. Catalytic behavior of supported Ru nanoparticles on the $\left\{\begin{array}{lll}1 & 0 & 0\end{array}\right\},\{1$ $10\}$, and $\left\{\begin{array}{lll}1 & 1 & 1\end{array}\right\}$ facet of $\mathrm{CeO}_{2}$. J Catal 2015;329:177-86.

[30] Martin D, Duprez D. Evaluation of the acid-base surface properties of several oxides and supported metal catalysts by means of model reactions. J Mol Catal A-Chem 1997;118:113-28.

[31] Wang F, He S, Chen $\mathrm{H}$, et al. Active site dependent reaction mechanism over $\mathrm{Ru} / \mathrm{CeO}_{2}$ catalyst toward $\mathrm{CO}_{2}$ methanation. J Am Chem Soc 2016;138:6298-305.

[32] Winter L R, Chen R, Chen X, et al. Elucidating the roles of metallic Ni and oxygen vacancies in $\mathrm{CO}_{2}$ hydrogenation over $\mathrm{Ni} / \mathrm{CeO}_{2}$ using isotope exchange and in situ measurements. Appl Catal B: Environ 2019;245:360-66.

[33] Winter L R, Gomez E, Yan B, et al. Tuning Ni-catalyzed $\mathrm{CO}_{2}$ hydrogenation selectivity via Niceria support interactions and Ni-Fe bimetallic formation. Appl Catal B: Environ 2018;224:442-50.

[34] Lu H, Khan A, Pratsinis S E, et al. Flame-made durable doped-CaO nanosorbents for $\mathrm{CO}_{2}$ capture. Energy Fuels 2008;23:1093-100.

[35] Guo H, Kou X, Zhao Y, et al. Role of microstructure, electron transfer, and coordination state in 
the $\mathrm{CO}_{2}$ capture of calcium-based sorbent by doping (Zr-Mn). Chem Eng J 2018;336:376-85.

[36] Guo H, Kou X, Zhao Y, et al. Effect of synergistic interaction between Ce and $\mathrm{Mn}$ on the $\mathrm{CO}_{2}$ capture of calcium-based sorbent: Textural properties, electron donation, and oxygen vacancy. Chem Eng J 2018;334:237-46.

[37] Li M, Amari H, van Veen A C. Metal-oxide interaction enhanced $\mathrm{CO}_{2}$ activation in methanation over ceria supported nickel nanocrystallites. Appl Catal B: Environ 2018;239:27-35.

[38] Yang L, Pastor-Pérez L, Gu S, et al. Highly efficient $\mathrm{Ni} / \mathrm{CeO}_{2}-\mathrm{Al}_{2} \mathrm{O}_{3}$ catalysts for $\mathrm{CO}_{2}$ upgrading via reverse water-gas shift: Effect of selected transition metal promoters. Appl Catal B: Environ 2018;232:464-71. 